\title{
Familial hyperaldosteronism type II
}

INSERM

\section{Source}

INSERM. (1999). Orphanet: an online rare disease and orphan drug data base. Familial hyperaldosteronism type II. ORPHA:404

Familial hyperaldosteronism type II (FH-II) is a heritable form of primary aldosteronism (PA) characterized by hypertension of varying severity, and non glucocticoid remediable hyperaldosteronism. 